\title{
Selected Nigerian Local Diet Effects on Blood Glucose Response of Undergraduates of Imo State University, Owerri
}

\author{
Onyeneke Esther-Ben Ninikanwa ${ }^{1, ~ *, ~ O l a w u n m i ~ I j e o m a ~}{ }^{2}$, Adedokun Ishola Isaaq ${ }^{3}$, \\ Obichere Goddard Chiedubem ${ }^{1}$ \\ ${ }^{1}$ Department of Nutrition and Dietetics, Faculty of Health Sciences, Imo State University, Owerri, Nigeria \\ ${ }^{2}$ Department Food Science and Technology, School of Engineering and Engineering Technology, Federal University of Technology, Owerri, \\ Nigeria \\ ${ }^{3}$ Department Food Science and Technology, Imo State Polytechnic Umuagwo, Ohaji, Nigeria
}

Email address:

estyninika@gmail.com (O. Esther-Ben N.)

${ }^{*}$ Corresponding author

To cite this article:

Onyeneke Esther-Ben Ninikanwa, Olawunmi Ijeoma, Adedokun Ishola Isaaq, Obichere Goddard Chiedubem. Selected Nigerian Local Diet Effects on Blood Glucose Response of Undergraduates of Imo State University, Owerri. International Journal of Nutrition and Food Sciences. Vol. 9, No. 3, 2020, pp. 69-77. doi: 10.11648/j.ijnfs.20200903.11

Received: October 5, 2019; Accepted: February 11, 2020; Published: May 27, 2020

\begin{abstract}
The effects of some local diets on the blood glucose response of Ten (10) selected undergraduates of Imo State University were investigated. The food samples investigated were glucose (control), breadfruit cake (Treculiaafricana), egusi cake (Agbaratti, Kpurukpuru, Mgbam) (Citruluslanatus) and groundnut soup (Arachis hypogea). The breadfruit was washed, boiled and cooked with other ingredients such as palm oil, pepper, onions, maggi and salt. The egusi sample was sorted, milled and pepper, onions, red oil and salt added. It was molded into shape, wrapped in a leaf (nturukpa) and boiled. The groundnut was sorted and milled and used to prepare groundnut soup. The result obtained from the study revealed that Sample B (breadfruit cake) has the highest moisture content (55.77\%). Sample E (egusi cake) recorded the highest protein (33.39\%). Sample G (groundnut soup) has the highest fat (12.24\%) and ash (3.21\%) content. Crude fiber was highest in Sample G (groundnut soup) (2.00\%). The highest carbohydrate was seen in Sample B (breadfruit cake) $(20.14 \%)$ while (Sample G) groundnut soup has the least (5.30\%). The overall acceptability of Sample B (breadfruit cake) is higher (8.1\%) compared to the overall rating of other food samples. However, no significant difference $(\mathrm{p}>0.05)$ existed in overall rating scores of the food samples. The blood glucose response result shows that Glucose has it's peak at 30 minutes $(118.20 \mathrm{mg} / \mathrm{dl})$ followed by Sample B (breadfruit cake) (115.0mg/dl) while Egusi cake has the lowest response $(82 \mathrm{mg} / \mathrm{dl})$. A close relationship was observed between the responses of glucose and Sample B (breadfruit cake) at 15 minutes $(94.1 \mathrm{mg} / \mathrm{dl}$ and $96.9 \mathrm{mg} / \mathrm{dl}), 30$ minutes $(118.2 \mathrm{mg} / \mathrm{dl}$ and $115 \mathrm{mg} / \mathrm{dl})$ and $45 \mathrm{minutes}(111.3 \mathrm{mg} / \mathrm{dl}$ and $118.3 \mathrm{mg} / \mathrm{dl}$ ) which suggest that Sample B (breadfruit cake) contains more carbohydrate than the other test foods. The glycemic index has been recommended to help guide food choice because low-glycemic index foods have been shown to improve blood glucose control in people with diabetes and to increase insulin sensitivity and $\beta$-cell function.
\end{abstract}

Keywords: Local Diets, Undergraduates of Imo State University, Blood Glucose Response

\section{Introduction}

\subsection{Glycemic Index of Foods}

Glycemic index (G.I) is the measure of the rate at which an ingested food causes the level of glucose in the body to rise; this is mainly caused by carbohydrate food [21]. It is a system that ranks food at the rate at which their carbohydrates are converted into glucose in the body. It can also be said to be the measure of the effect of food on the blood sugar levels [21]. The glycemic index compares the blood sugar responses to a particular food to the body's reaction to pure glucose which is given a value of 100 and also used as the main reference point. For instance if a food 
raises the blood sugar levels only half as pure glucose, the food receives a glycemic index of (50) [21]. The glycemic index consist of a scale from 1-100, indicating the rate at which 50 grams of carbohydrate in a particular food is absorbed into the blood stream as blood sugar [19.]

\subsection{Factors That Influence Glycemic Index}

Many factors together including carbohydrate type, fiber, protein, fat, food form and method of preparation, influences the glycemic index of a particular food [4]. Some factors that affect the glycemic index of foods includes; processing, fiber content, fat, method of preparation and the amount eaten. The glycemic index value of foods is determined by measuring out $50 \mathrm{~g}$ portion of digestible carbohydrate of the test food and administering it to patients/subjects for investigations. Their blood glucose levels is checked every 30 minutes for 2 hours and compared against glucose which is used as a reference point [15]. Foods are classified based on the glycemic index value into high, moderate and low glycemic foods [7]. The contribution of glycemic index to nutrition therapy and medical dietetics cannot be over emphasized and yet very little is known about the glycemic index value of most foods we consume. Less effort has been concentrated on the glycemic index value of most commonly consumed Nigerian foods. The knowledge of the glycemic index value of food is not only limited to diabetics alone, as it can be used to treat obesity which is also very prevalent in our society and insulin insensitivity. The above background motivated the research towards determining the effects of some commonly consumed foods and its corresponding glycemic responses on undergraduates. The result of this study will be of immense significance to dietitians and nutritionists as it will encourage them to use the glycemic index as a tool in the diet therapy.

\section{Materials and Methods}

\subsection{Procurement of Materials}

All the materials needed for the experiment (Egusi, Breadfruit, and Groundnut) were purchased randomly from Relief market in Owerri, Imo State.

Glucometer /Blood glucose testing meter, Box of test strips, Sterile Lancet, Cotton wool or gauze swabs, Nonsterile gloves, Sharps container, Methylated spirit, Evans glucose (glucose - D), Weighing scale

\subsection{Sample Collection}

Evans glucose was purchased from the market. Mature fruit samples of Treculiaafricana were bought from Relief market. Two bottles of fried groundnut was bought. Required quantity of egusi was bought from the named market.

\subsection{Sample Processing}

\subsubsection{Egusi Cake Preparation}

$2.5 \mathrm{~kg}$ of dehulled melon seed known as "egusi" was ground alongside $1.5 \mathrm{~kg}$ of usu, a thickener with $150 \mathrm{~g}$ (3 bulbs) of sliced onions until a paste was formed, and $300 \mathrm{ml}$ of hot water was added. The mixture was placed in a bowl and 2 cooking spoons of red oil, pepper and salt were added and mixed together. The melon paste was then molded into a desirable size using the hands and wrapped with a leaf (etere). Then it was placed into $3000 \mathrm{ml}$ of boiling water in a cooking pot on a cooking gas and was allowed to boil for about 50mins under mild heat until it cakes.

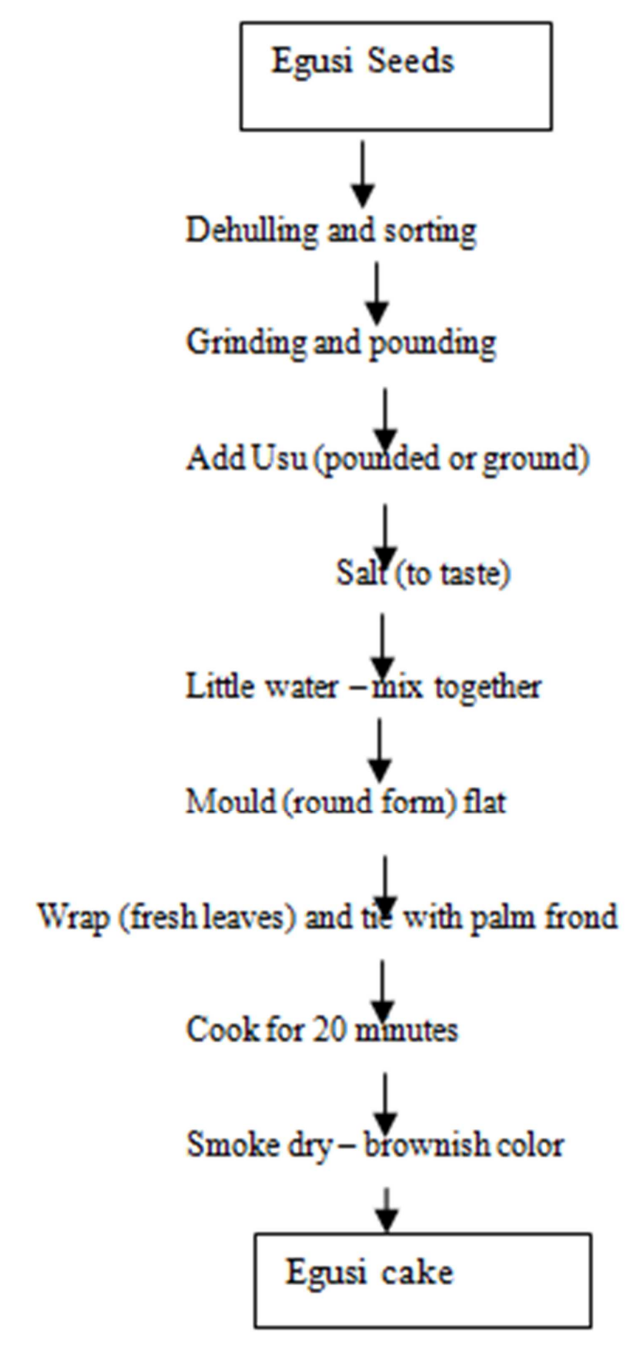

Figure 1. Flow chart for the preparation of egusi cake as described [16].

\subsubsection{Preparation of Breadfruit Cake}

The African breadfruit was thoroughly washed to remove dirt and unwanted materials. They were peeled and washed with clean water. It was placed in a clean pot and water was added just the same level as the breadfruit and allowed to boil. After about 15-20 minutes, trona (kaun) was dissolved in $70 \mathrm{mls}$ of water and strained using a sieve of $0.5 \mathrm{~mm}$ mesh size. Palm oil, onions, pepper and magi were added. Salt was also added to taste and stirred. The food was covered and allowed to boil for a further 45 minutes to 1 hour till done. When done, a spatula was used to mix the food at 5 minutes interval till it cakes. 


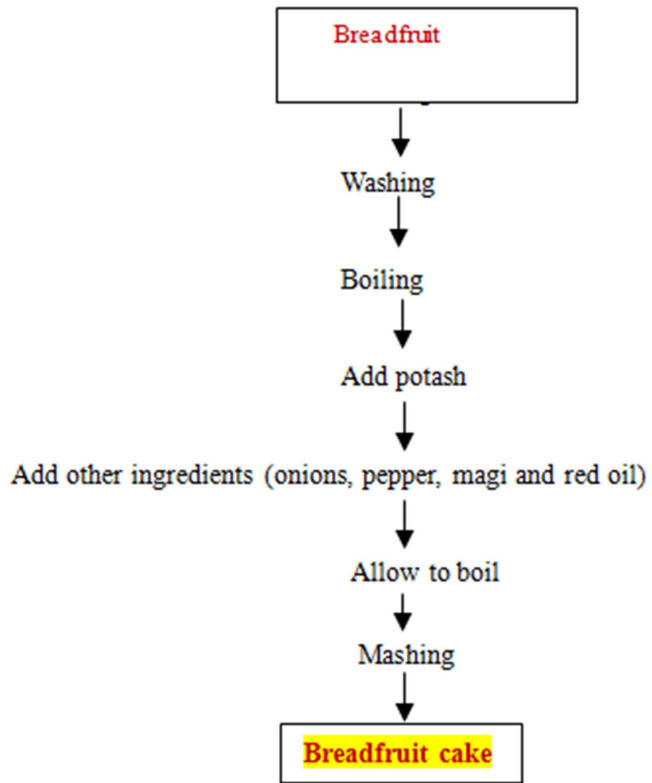

Figure 2. Flowchart of preparation of Bread fruit Cake as described [11].

\subsubsection{Preparation of Groundnut Soup}

The soup was prepared by washing $700 \mathrm{~g}$ of red meat, $400 \mathrm{~g}$ of dried fish which was placed inside a cooking pot and was allowed to heat for about $10 \mathrm{mins}$ on a gas cooker. Then 2 cooking spoons of palm oil was introduced followed by the groundnut paste. After which $50 \mathrm{~g}$ of crayfish, $10 \mathrm{~g}$ of fresh pepper, two cubes of maggi and about $500 \mathrm{ml}$ of water were all added and allowed to boil for about 30mins, Salt was added to taste and the mixture allowed to heat for 3 mins till the soup was ready [11].

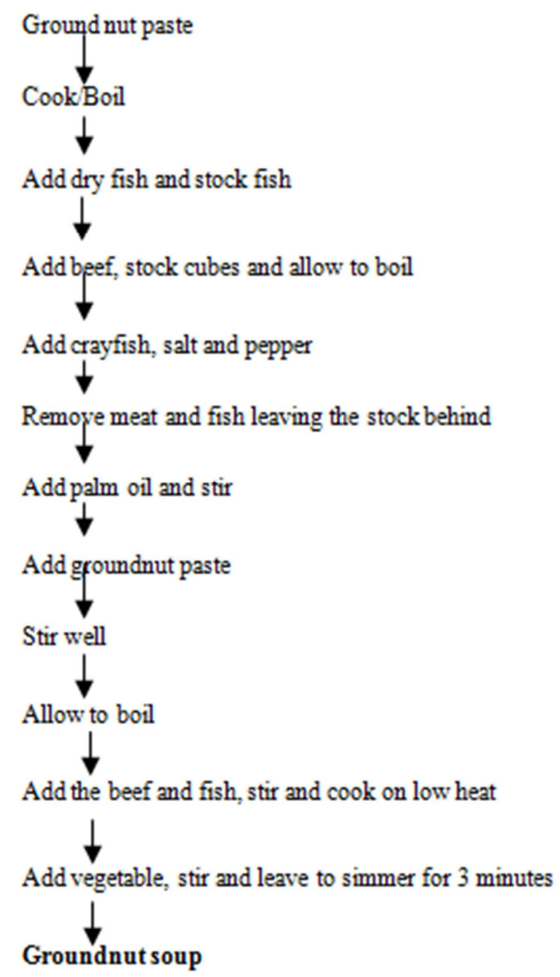

Figure 3. Flowchart of preparation of Groundnut Soup as described by
$[11] .$.

\subsection{Determination of Glycemic Response of Volunteers}

The procedure for determining the glycemic response of volunteers is as described by [20]. Following 12 hour fast, 10 volunteers ate $25 \mathrm{~g}$ available carbohydrate portions of the standard reference food (glucose) dissolved in $200 \mathrm{mls}$ of water and other food samples at random on different days. The standard food was repeated three times in each subject and their mean IAUC value was calculated as the IAUC of the glucose.

$400 \mathrm{mls}$ of table water was given to each of the volunteers so that total meal volume is greater than $300 \mathrm{ml}$ to stimulate stomach emptying and reduce the variability of glycemic responses. The foods were consumed within 10-15 minutes and the volunteers were asked to remain seated for the duration of the test. Finger prick capillary blood samples was taken from volunteers using lancets before eating the meals (0 minutes) and at 15, 30, 60, 90 and 120 minutes intervals after consumption of the meals, whole blood glucose was measured by dropping the volunteers blood at each of the intervals in a test strip and inserting at the test spot of a glucometer (a one touch basic system glucometer) and reading taken immediately. Incremental Area Under Curve (IAUC) was measured geometrically using the data obtained from the blood glucose concentration, time graph ignoring area beneath the fasting level.[20]

\subsection{Survey Design}

A random sampling was used for the study.

\subsubsection{Population of Study}

Ten undergraduate students from the Department of Nutrition and Dietetics, Faculty of Health Sciences aged 2024 years old were used for the study.

\subsubsection{Sample Selection}

A random selection was done after which ten healthy nondiabetic undergraduate students were selected for the study. The goal and objectives of the study including skipping breakfast in order to carry out fasting blood sugar was explained.

\subsubsection{Sample Size Determination}

The sample size was determined using this formula

$$
n=\frac{N}{1+\left(e^{2}\right)}
$$

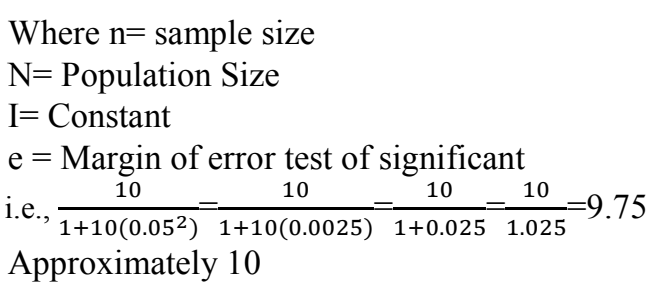

\subsubsection{Recruiting of Research Assistance}

A 400 level medical laboratory student of Imo State University, Owerri was recruited for blood sample collection 
and determination of blood glucose response. The objectives and techniques of the study were explained to her.

\subsubsection{Determination of Glycemic Response of Volunteers}

The procedure for determining the glycemic response of volunteers [21]. Following 12 hour fast, 10 volunteers ate $25 \mathrm{~g}$ available carbohydrate portions of the standard reference food (glucose) dissolved in $200 \mathrm{mls}$ of water and other food samples at random on different days. The standard food was repeated three times in each subject and their mean IAUC value was calculated as the IAUC of the glucose. $400 \mathrm{mls}$ of table water was given to each of the volunteers so that total meal volume is greater than $300 \mathrm{ml}$ to stimulate stomach emptying and reduce the variability of glycemic responses. The foods were consumed within 10-15 minutes and the volunteers were asked to remain seated for the duration of the test. Finger prick capillary blood samples was taken from volunteers using lancets before eating the meals ( 0 minutes) and at 15, 30, 60, 90 and 120 minutes intervals after consumption of the meals, whole blood glucose was measured by dropping the volunteers blood at each of the intervals in a test strip and inserting at the test spot of a glucometer (a one touch basic system glucometer) and reading taken immediately. Incremental Area Under Curve (IAUC) was measured geometrically using the data obtained from the blood glucose concentration, time graph ignoring are beneath the fasting level [23].

\subsubsection{Determination of Glycemic Index}

The incremental area under the curve (IAUC) was calculated for each meal in every volunteer separately (as the sum of the surface of triangles and trapezoids between the Bglucose curve and horizontal baseline going parallel to $\mathrm{x}$-axis from the beginning of B-glucose curve at time 0 to the point at time $120 \mathrm{~min}$ ) to reflect the total rise in B-glucose concentration after eating the tested food. The IAUCS for the standard reference food (i.e. $25 \mathrm{~g}$ of pure glucose) was obtained similarly to the mean from the first three independent $\mathrm{IAUCR}_{1}, \mathrm{IAUCR}_{2}, \mathrm{IAUCR}_{3}$ in the same volunteer.

In each volunteer, the glycemic index (\%) was calculated by dividing the IAUC for the tested food by the IAUCS for the standard food and multiplying by 100 . The following formula was used:

\section{G.I $=$ IAUC of the tested meal $\times 100$}

Mean IAUCRof reference food

IAUC - Incremental Area Under the blood glucose response Curve for the tested meal

IAUCR - Incremental Area Under the blood glucose response Curve for the reference meal

The glycemic index for each tested food was calculated as the mean from the respective average glycemic indices of the 10 volunteers.

\subsubsection{Data Collection}

Each of the samples (3 in number) was collected in a plastic container. The ingredients for the 3 food samples, quantities and methods used in soup preparation were recorded. The collected samples were stored in a deep freezer until used for analysis.

\subsubsection{Statistical Analysis}

Means and standard deviation were subjected to analysis of Variance (ANOVA) to see if there are significant differences among the five food samples in their proximate composition [18]. Turkey LSD test was used to identify significant difference at $5 \%$ level of probability.

\subsection{Data Analysis}

All determinations were done in triplicates. The methods described below were used for the specific analysis.

\subsubsection{Sensory Evaluation of the Food Samples}

Organoleptic attributes (color, texture, aroma, mouth feel and general acceptability) of the food samples were evaluated using a nine point hedonic scale [8]. 10 subjects selected among the undergraduates were selected as judges for the study. The judges were asked to taste each of the food samples for color, mouth feel, aroma, texture and general acceptability and indicate their feeling about the product on the sensory evaluation sheet.

\subsubsection{Proximate Analysis}

A standardized method to determine the values of the macronutrients in the food samples using chemical nutritional analytical processes was employed

\subsubsection{Moisture Determination}

This was done by the gravimetric method [2]. A measured weight of the sample $(5.0 \mathrm{~g})$ was weighed into a previously weighed moisture can. The sample in the can was dried in the oven at $105^{\circ} \mathrm{C}$ for 3 hours. It will be cooled in a desiccator and weighed. It was then returned to the oven for further drying. Drying, Cooling and weighing were done repeatedly at hourly (one hour) interval until there are no further diminutions in the weight (ie constant weight was obtained). The weight of moisture lost was calculated' and expressed as a percentage of the weight of sample analyzed. It is given by the expression below.

$$
\% \text { Moisture content }=100 / 1 \times \mathrm{W}_{2}-\mathrm{W}_{3} / \mathrm{W}_{2}-\mathrm{W}_{1}
$$

Where W1 = Weight of empty moisture can W2 =Weight of empty can + sample before dying W3 =Weight of can + sample dried to constant weight

\subsubsection{Determination of Protein}

This was done by the Kjeldahl method described by James [10]. The total Nitrogen was determined and multiplied with factor 6.25 to obtain the protein procedures. Half gram $(0.5 \mathrm{~g})$ of the sample was mixed with $10 \mathrm{mls}$ of Conc. $\mathrm{H}_{2} \mathrm{SO}_{4}$ in a digestion flask. A tablet of selenium catalyst was added to it before it was heated under a fume cupboard until a clear solution is obtained (i.e. the digest).

The digest was diluted to $100 \mathrm{mls}$ in a volumetric flask and used for the analysis. $10 \mathrm{mls}$ of the digest was mixed with equal volume of $45 \% \mathrm{NaOH}$ solution in a Kjeldahl 
distillation apparatus. The mixture was distilled into $10 \mathrm{ml}$ of $4 \%$ buric acid containing 3 drops of mixed indicator (bromocressol green/methyl red) a total of $50 \mathrm{mls}$ of distillate was collected and titrated against $0.02 \mathrm{M}$ EDTA from green to a deep red end point. A reagent blank was also digested, distilled and titrated. The $\mathrm{N}_{2}$ content and hence the protein content was calculated using the formula below.

$$
\begin{gathered}
\text { 1Mole of } \mathrm{INH}_{2} \mathrm{SO}_{4}=14 \mathrm{mgN}_{2} \\
\% \text { Protein }=\% \mathrm{~N}_{2} \times 6.25 \\
\% \mathrm{~N} 2=\{100 \\
\% N_{2}\left\{\frac{10}{W} \times \frac{N \times 14}{100} \times \frac{V_{t}}{V_{a}}\right\} T
\end{gathered}
$$

$\mathrm{W}=$ Weight of sample $(0.5 \mathrm{~g})$

$\mathrm{N}=$ Normality of titrant $\left(0.02 \mathrm{~N} \mathrm{H}_{2} \mathrm{SO}_{4}\right)$

$\mathrm{Vt}=$ Total digest volume $(100 \mathrm{mls})$

$\mathrm{Va}=$ volume of digest analyzed $(10 \mathrm{ml})$

$\mathrm{T}=$ Sample titre value

$\mathrm{B}=$ Blank titre value

\subsubsection{Determination of Ash}

This was done by the furnaces incineration gravimetric method [2] $5.0 \mathrm{~g}$ of the processed sample was measured into a previously weighed porcelain crucible. The sample was burnt to ashes in a muffle furnace at $550^{\circ} \mathrm{C}$. When it became completely ashed, it was cooled in a desiccator and weighed. The weight of ash obtained was calculated by difference and expressed as a percentage of the weight of sample analyzed as shown below.

$$
\% \text { Ash }=100 / 1 \times \mathrm{W}_{2}-\mathrm{W}_{1} / \mathrm{Wt} \text { of Sample }
$$

Where $\mathrm{W} 1=$ Weight of empty crucible

W2 = Weight of crucible + ash.

\subsubsection{Determination of Crude Fiber}

The Wende Method [2] was employed. 5.0g of the processed sample was boiled in $150 \mathrm{mls}$ of $1.25 \% \mathrm{~N}_{2} \mathrm{SO}_{4}$ solution for 30 minutes under reflux. The boiled sample was washed in several portions of hot water using a twofold Muslim cloth to trap the particles. It was returned to the flask and boiled again in $150 \mathrm{mls}$ of $1.25 \% \mathrm{NaOH}$ for another 30 minuts under same condition. After washing in severalportion of hot water, the sample was allowed to drain dry before being transferred quantitatively to a weighed crucible where it was aired in the oven at 10Soc to a constant weight. It was thereafter taken to a muffle furnace in which it was burnt until only ash is left of it. By difference, the weight of fiber was obtained and expressed as a percentage of the weight of sample analyzed. It is given by the formula below.

$$
\% \text { Crude Fiber }=100 / 1 \times \mathrm{W}_{2}-\mathrm{W}_{3} / \mathrm{Wt} \text { of Sample }
$$

Where W2 = Weight of crucible + sample after boiling, washing and drying

W3 $=$ Weight of crucible + sample as ash.

\subsubsection{Determination of Fat}

The solvent extraction gravimetric method [2] was used, $5.0 \mathrm{~g}$ of the sample was wrapped in a porous paper (Whiteman filter paper) and put in a thimble, The thimble was put in a Sohxlet reflux flask and mounted into a weigh extraction flask containing $200 \mathrm{mls}$ of petroleum ether. The upper end of the reflux flask was connected to a water condenser. The solvent (petroleum ether) was heated; it boiled, vaporized and condensed into the reflux flask. Soon the sample in the thimble was covered with the solvent, which contract the oil (fat). The sample remained in contact with the solvent until the reflux flask was filled up and siphoned over, carrying its oil extract down to the boiling flask. This process was allowed to go on repeatedly for 4hours before the defatted sample was removed, the solvent recovered and the oil extract was in the flask. The flask (containing the oil extract), was dried in the oven at $60^{\circ} \mathrm{C}$ for 30 mins (to remove any residual solvent). It was cooled in desiccators and weighed. By difference, the weight of oil (fat) extract was determined and expressed as a percentage of the weight of sample analyzed and given by the expression below;

$$
\% \text { Fat }=\frac{W_{2}-W}{\text { Wt of Sample }} \times \frac{100}{1}
$$

$\mathrm{W}_{1}$ - Initial weight, $\mathrm{W}_{2}$-Final weight.

\subsubsection{Determination of Carbohydrates}

It will be calculated using the formula below as described by [9].

$\%$ Carbohydrate $=100 \%$ (protein + fat + fiber + ash + moisture content).

\section{Results}

Table 1 Proximate composition of the food samples.

The proximate composition of the food samples are presented in table 1 . There was significant difference $(p<0.05)$ in the mean values of proximate composition. Sample B has the highest moisture content (55.77\%), followed by (Sample G) groundnut soup (46.12\%) with (Sample E) egusi cake having the lowest moisture content (41.56\%). Sample E egusi cake recorded the highest protein content $(33.39 \%)$ while (Sample B) breadfruit cake has the least $(14.04 \%)$. Sample G (groundnut soup) has the highest fat $(12.24 \%)$ and ash (3.21\%) content while Sample B breadfruit cake recorded the least in the two parameters; fat $(7.48 \%)$ and ash $(1.37 \%)$. Crude fiber content of (Sample G) groundnut soup $(2.00 \%)$ is the highest while (Sample B) breadfruit cake recorded the lowest $(1.05 \%)$ crude fiber content. The highest carbohydrate content was seen in (Sample B) breadfruit cake (20.14\%) while (Sample G) groundnut soup contains the least carbohydrate (5.30\%).

Table 2 Sensory evaluation of the food samples

(Sample B) breadfruit cake recorded the highest colour content $(8.0 \%)$ while both (Sample E) egusi cake and (Sample G) groundnut soup recorded the lowest (7.1\%). 
However, there is no significant difference between the two food samples. The aroma of the food samples significantly increased $(\mathrm{p}<0.05)$ with (Sample E) egusi cake recording the highest aroma $(8.0 \%)$ while (Sample G) groundnut soup recorded the lowest $(7.2 \%)$. The taste of the food samples also varied significantly $(\mathrm{p}<0.05)$ with (Sample $\mathrm{G})$ groundnut soup having the highest taste $(7.8 \%)$ and (Sample E) egusi cake the lowest $(6.7 \%)$. (Sample B) breadfruit cake has the highest texture $(7.7 \%)$ while (Sample E) egusi cake has the lowest $(6.8 \%)$. The overall acceptability of (Sample E) breadfruit cake is higher $(8.1 \%)$ than the rest of the food samples while there is no significant difference between that of (Sample E) egusi cake and (Sample G) groundnut soup, both having $7.4 \%$

Table 1. Mean values of proximate composition of the food samples.

\begin{tabular}{lllll}
\hline Parameters & Sample E & Sample B & Sample G & LSD (P<0.05) \\
\hline Moisture content \% & $41.5650^{\mathrm{c}}+0.02$ & $55.7750^{\mathrm{a}}+0.02$ & $46.1250^{\mathrm{b}}+0.02$ & 0.2121 \\
Protein \% & $33.3950^{\mathrm{a}}+0.02$ & $14.0450^{\mathrm{c}}+0.02$ & $31.1200^{\mathrm{b}}+0.01$ & 0.01915 \\
Fat \% & $12.0350^{\mathrm{b}}+0.02$ & $7.4800^{\mathrm{c}}+.03$ & $12.2400^{\mathrm{a}}+0.02$ & 0.02380 \\
Ash \% & $2.6200^{\mathrm{b}}+0.01$ & $1.3700^{\mathrm{c}}+0.01$ & $3.2150^{\mathrm{a}}+0.007$ & 0.01225 \\
Crude fiber \% & $2.1550^{\mathrm{a}}+0.01$ & $1.0550^{\mathrm{c}}+0.02$ & $2.0050^{\mathrm{b}}+.007$ & 0.01528 \\
Carbohydrate\% & $7.9150^{\mathrm{b}}+0.06$ & $20.1450^{\mathrm{a}}+0.10$ & $5.300^{\mathrm{c}}+0.04$ & 0.07550 \\
\hline
\end{tabular}

Mean values with different superscripts are significantly different $(\mathrm{p}<0.05)$ in the same column, LSD $=$ Least significant difference.

KEY - Sample B = breadfruit cake

Sample E = egusi cake

Sample $\mathrm{G}=$ groundnut soup

Table 2. Mean scores of sensory attributes of the food samples.

\begin{tabular}{|c|c|c|c|c|}
\hline Parameters & Sample E & Sample B & Sample G & LSD $(P<0.05)$ \\
\hline Colour & $7.1000^{\mathrm{ab}}+1.52$ & $8.0000^{\mathrm{a}}+0.94$ & $7.1000^{\mathrm{ab}}+0.87$ & 0.51496 \\
\hline Aroma & $8.0000^{c}+1.33$ & $7.4000^{b}+0.69$ & $7.2000^{\mathrm{a}}+0.91$ & 0.45542 \\
\hline Taste & $6.7000^{b}+1.63$ & $8.3000^{c}+0.67$ & $7.8000^{\mathrm{a}}+1.03$ & 0.52915 \\
\hline Texture & $6.8000^{\mathrm{b}}+1.68$ & $7.7000^{\mathrm{a}}+1.25$ & $7.0000^{\mathrm{c}}+1.41$ & 0.65376 \\
\hline Overall acceptability & $7.4000^{\mathrm{ab}}+1.42$ & $8.1000^{\mathrm{a}}+0.31$ & $7.4000^{\mathrm{ab}}+0.69$ & 0.41899 \\
\hline
\end{tabular}

Mean values with different superscripts are significantly different $(\mathrm{p}<0.05)$ in the same column, $\mathrm{LSD}=$ Least significant difference.

$\mathrm{KEY}$ - Sample B = breadfruit cake

Sample E $=$ egusi cake

Sample $\mathrm{G}=$ groundnut soup

Table 3 Glucose Response Level (GRL) of the Foods on the Subjects

Table 3 below shows the mean glucose response level of the food samples on the subjects at $0,15,30,45,60,90$ and 120 minutes. There was no significant difference on the fasting blood glucose of Sample E, and Sample B respondents. There was a significant difference $(p<0.05)$ in the overall blood glucose response of the respondents. (Sample B) breadfruit cake recorded the highest blood glucose response $(96.90 \mathrm{mg} / \mathrm{dl})$ at 15 minutes while having it's peak at 45 minutes $(118.30 \mathrm{mg} / \mathrm{dl})$. (Sample E) egusi cake has the least response at 15 minutes $(78.30 \mathrm{mg} / \mathrm{dl})$ with it's peak at 90 minutes $(88.8 \mathrm{mg} / \mathrm{dl})$. Glucose has it's peak at 30 minutes $(118.20 \mathrm{mg} / \mathrm{dl})$ followed by (Sample B) breadfruit cake $(115.0 \mathrm{mg} / \mathrm{dl})$ while Egusi cake has the lowest response $(82 \mathrm{mg} / \mathrm{dl})$. The table also revealed a close relationship between the responses of glucose and (Sample B) breadfruit cake at 15 minutes $(94.1 \mathrm{mg} / \mathrm{dl}$ and $96.9 \mathrm{mg} / \mathrm{dl}), 30$ minutes $(118.2 \mathrm{mg} / \mathrm{dl}$ and $115 \mathrm{mg} / \mathrm{dl})$ and 45 minutes $(111.3 \mathrm{mg} / \mathrm{dl}$ and $118.3 \mathrm{mg} / \mathrm{dl}$ ) which suggests that (Sample B) breadfruit cake contains more carbohydrate than the other test foods. However, the result states that the (Sample G) groundnut soup continued increasing even till 120 minutes $(92.3 \mathrm{mg} / \mathrm{dl})$

Table 3. Mean values of Glucose response level (GRL) of indigenous foods fed respondents.

\begin{tabular}{|c|c|c|c|c|c|}
\hline Parameters & Glucose & Sample E & Sample B & Sample G & LSD $(\mathrm{P}<0.05)$ \\
\hline GRL at $0 \mathrm{~min}$ & $78.50^{\mathrm{b}}+5.68$ & $81.20^{\mathrm{ab}}+6.39$ & $81.40^{\mathrm{ab}}+4.81$ & $87.0^{\mathrm{a}}+3.62$ & 2.33868 \\
\hline GRL at $15 \mathrm{~min}$ & $94.10^{\mathrm{a}}+7.32$ & $78.30^{\mathrm{b}}+5.98$ & $96.90^{\mathrm{a}}+9.92$ & $85.0^{\mathrm{b}}+3.80$ & 3.18146 \\
\hline $\mathrm{GRL}$ at $30 \mathrm{~min}$ & $118.20^{\mathrm{a}}+9.22$ & $82.0^{\mathrm{b}}+5.75$ & $115.0^{\mathrm{a}}+9.49$ & $86.10^{\mathrm{b}}+3.10$ & 3.30194 \\
\hline $\mathrm{GRL}$ at $45 \mathrm{~min}$ & $111.30^{\mathrm{a}}+9.09$ & $83.30^{\mathrm{b}}+4.85$ & $118.30^{\mathrm{a}}+11.60$ & $87.50^{\mathrm{b}}+4.24$ & 3.59846 \\
\hline $\mathrm{GRL}$ at $60 \mathrm{~min}$ & $97.20^{b}+12.60$ & $86.70^{b}+5.73$ & $115.30^{\mathrm{a}}+12.88$ & $88.0^{\mathrm{b}}+3.29$ & 4.29328 \\
\hline GRL at $90 \mathrm{~min}$ & $83.90^{\mathrm{b}}+7.68$ & $88.80^{\mathrm{b}}+5.30$ & $105.90^{\mathrm{a}}+13.86$ & $91.50^{\mathrm{b}}+4.88$ & 3.89437 \\
\hline GRLat $120 \mathrm{~min}$ & $80.50^{\mathrm{b}}+4.83$ & $84.00^{\mathrm{b}}+3.52$ & $93.70^{\mathrm{a}}+10.01$ & $92.30^{\mathrm{a}}+4.11$ & 2.76556 \\
\hline
\end{tabular}

Mean values with different superscripts are significantly different $(\mathrm{p}<0.05)$ in the same column, $\mathrm{LSD}=\mathrm{Least}$ significant difference, $\mathrm{GRL}=\mathrm{Glucose}$ response level, $\mathrm{N}=$ Number of respondents fed per day (10 people).

$\mathrm{KEY}-$ Glucose $=$ Reference food, Sample E = egusi cake

Sample B = breadfruit cake

Sample $\mathrm{G}=$ groundnut soup 
Table 4. Glycemic index classification of selected local diets.

\begin{tabular}{lllll}
\hline Food & GI & Classification & GL & Classification \\
\hline Egusi cake & 20 & Low & 5 & Low \\
Breadfruit cake & 61 & Moderate & 15 & Moderate \\
Groundnut soup & 15 & Low & 4 & Low \\
\hline
\end{tabular}

$\mathrm{GI}=$ Glycemic index, GL $=$ Glycemic load

Mean values with different superscripts are significantly different $(p<0.05)$ in the same column.

KEY -Glucose $=$ Reference food, Sample E = egusi cake

Sample B = breadfruit cake

Sample $\mathrm{G}=$ groundnut soup

\section{Discussion}

\subsection{Proximate Composition of the Food Samples}

Table 1 shows the proximate composition of the food samples. There is a significant difference $(p<0.05)$ in the moisture content of the samples. Breadfruit cake recorded the highest moisture content $55.77 \%$ followed by groundnut soup $46.12 \%$ and lastly egusi cake which has $41.56 \%$. The high levels of moisture in all the samples investigated suggests that the indigenous diets would not store for long without spoilage since high water activity could enhance microbial action bringing about food spoilage. The result of protein content of indigenous foods indicated that egusi cake has the highest protein content $33.39 \%$ followed by groundnut soup $31.12 \%$ while breadfruit cake recorded the least $14.04 \%$. The protein value of breadfruit $14.04 \%$ was significantly higher $(p<0.05)$ than that reported by [17] $12.47 \%$. The crude protein values obtained in this study did not differ significantly from the values reported by other authors [10]

However, a study reported by [3] reveals that the protein content of breadfruit $17.18 \%$ was significantly $(p<0.05)$ higher than that obtained from the present study. This suggests that the food sample can be used to enhance the protein content of foods.

Groundnut soup and Egusi cake both recorded higher values of fat $(12.24 \%$ and $12.03 \%$ respectively) against breadfruit cake with only $7.48 \%$. The breadfruit cake recorded the highest carbohydrate $20.145 \%$, while the least was observed in groundnut soup 5.3\%. Breadfruit cakemay be ranked as carbohydrate rich due to itshigh carbohydrate contents. Thus, it could serve as agood source of energy. The seeds may also serve as araw material for production of snacks cookies. The crude fiber of breadfruit cake $1.05 \%$ obtained tallied with that reported by [3] $1.04 \%$. The fat content of the breadfruit sample obtained $7.4 \%$ was significantly higher $(p<0.05)$ than that reported by [3] $6.4 \%$. This may be due to the quantity of oil added to the breadfruit during preparation which may help increase the energy content of the food and thus provide a suitable source of energy.

The study revealed that the proximate composition of groundnut soup obtained were $46.12 \%$ moisture content, $31.12 \%$ protein, $12.24 \%$ fat, $3.21 \%$ ash, $2.00 \%$ crude fiber and $5.30 \%$ carbohydrate. The values obtained for crude protein, crude fiber and ash were not significantly different
( $p>0.05)$ from $(38.6 \%, 2.7 \%$ and $4.8 \%$ ) respectively as reported by [1]. The high protein content of groundnut soup suggests that it can be included in complementary foods and thus improve the nutritional content of food.

The proximate composition of egusi cake obtained were $41.56 \%$ moisture, $33.39 \%$ protein, $12.03 \%$ fat, $2.62 \%$ ash, $2.15 \%$ crude fiber and $7.91 \%$ carbohydrate. The ash and protein contents of the sample were in agreement with $(2.22 \%$ and $30.16 \%)$ reported by [15] and values of 2.15 to $2.53 \%$ for ash reported by [13] and $38 \%$ protein reported by [14] this result shows that the food sample is more of a body building food and it contains some minerals needed to fuel metabolism. [5] reported a higher moisture content $49.40 \%$ as opposed to $41.56 \%$ obtained from the study. The crude fiber content $3.43 \%$ reported by [5] agrees with $3.57 \%$ obtained from the study. There is no significant difference $(\mathrm{p}<0.05)$ in carbohydrate content $7.22 \%$ reported by [8] with $7.915 \%$ obtained from the present study.

\subsection{Sensory Properties of the Indigenous Food Samples}

There was no significant difference $(p>0.05)$ in the colour of the egusi cake and groundnut soup as both samples recorded the same value $7.1 \%$, while breadfruit cake recorded the highest, $8.0 \%$. The taste of the food samples varied significantly $(\mathrm{p}<0.05)$ with breadfruit cake recording the highest taste $8.3 \%$ while egusi cake recorded the least $6.7 \%$. There was no significant difference in the texture and overall acceptability of the food samples. However all the samples were statistically similar and were accepted equally on the organoleptic characters tested.

\subsection{Glycemic Index of the Food Samples}

The glycemic index of breadfruit (61), was significantly higher than those of egusi cake (20), and groundnut soup (15). The glycemic index of the breadfruit (61) obtained from this study however agrees with (60), as reported by [20] for breadfruit eaten in the Carribean. When compared with the glycemic index of raw breadfruit which is 68 , it could be deduced from the study that there was a reduction in glycemic index of breadfruit which could be as a result of the oil used in preparing the food and also the effect of heat on the food. Breadfruit cake is therefore a moderate glycemic food. Study reported by [18] showed a glycemic index of (24) for boiled groundnut which varied significantly with that obtained from the present study (15) for groundnut.

\section{Conclusion}

Consuming too many higher or high-glycemic index starchy staples does not appear to be good enough for people in the general population, particularly, for the obesed, type- 2 diabetes and pre-diabetic patients. The selected Nigerian local diets has been shown to all be high in moisture content and so low keeping quality. Breadfruit showed the highest 
carbohydrate content and it compared favorably with glucose in terms of release of blood glucose. Interestingly, all selected indigenous diets are good sources of food nutrients and there exist a close relationship between the responses of glucose and their blood low glucose response. Legumes generally have a low glycemic index and are favorably used to monitor the blood glucose level of diabetics. They are useful tools in diet formulation.

\section{Recommendation}

The glycemic index has been recommended to help guide food choice because low glycemic index foods have been shown to improve blood glucose control in people with diabetes to increase insulin sensitivity and $\beta$-cell function (the part of the pancreas responsible for insulin secretion) and to reduce serum triacylglycerol. In addition, a lowglycemic index diet has been associated with reduced risk for developing diabetes and cardiovascular diseases and such local foods should be encouraged in consumption.

It is recommended that future work be done on keeping quality of the selected indigenous diets and their compatibility in diet formulation be increased.

\section{Acknowledgements}

First, we want to acknowledge the International Journal of Nutrition and Food, the Science Publishing Group (IJNFS) for this wonderful opportunity to publish. We appreciate all the reviewers of this work. we also thank all others who contributed to the success of this work, my colleagues, Dr Juan, Dr Hope, Dr Joy, Dr Ijeoma and the lovely family, of Benjamin Onyeneke and co. Finally, we Thank God for the gift of Life and strength to cope.

\section{References}

[1] J. A, Akinhanmi. Onuoha I. K. Adeleke Y. K., Osofisan A. O. Physicochemical component of legumes; Groundnut and Cowpea. Journal of Food Science and Technology. 2009 Volume 3 (6). $34-46$.

[2] Association of Official Analytical Chemists (AOAC) Official methods of analysis 20th ed. Washington DC, U.S.A) (2012).

[3] G. W Ayoade,., Aderibigbe, A., Amoo I. A.,. Effects of Different Processing Operations on Chemical Composition and Functional Properties of African Breadfruit (Treculiaafricana) seed. American Journal of Food Science and Nutrition Research 2015. Vol. 2, No. 6, pp. 180-185.

[4] H Granfeldt,, Lijeberg, J., Tovar, N. G. Asp Food properties affecting the digestion and absorption of carbohydrates. American journal of Clinical Nutrition 2014. $596995-7065$.

[5] R. U., EbanaC. A. Etok, and U. O. Edet, Nutritional and Microbial Analysis of Melon (Citrulluscolocynthis Linn) Cake and its Components - A Traditional Snack in South - South Nigeria International Journal of Innovation and Applied Studies. ISSN 2028-9324 2014. Vol. 8 pp. 1612-1617. Innovative Space of Scientific Research Journals http://www.ijias.issr-journals.org/
[6] D. J Gallant,., Bouchet, B., Buleon, A. \& Perez, S.,). Physical characteristics of starch granules and susceptibility to enzymatic degradation. European Journal of Clinical Nutrition 2012 46, Suppl. 2, S3 - S16.

[7] M., Gordonand Wardlaw J. H. S Perspective in Nutrition $7^{\text {th }}$ edition McGraw Hill New York., 2017. Pp, 171 -173. A63.

[8] A. I Ihekorornye, and Ngoddy, PIntegrated Food Science and technology of the tropic. Macmilliam Pub. Ltd. London 1985 $45-47$

[9] A. G Jacob,.., Etong, D. I., and Tijjani, A., Department of Applied Chemistry, Federal University Dutsin-Ma, Katsina State Proximate, Mineral and Anti-nutritional Compositions of Melon (Citrulluslanatus) Seeds 2015 British Journal of Researchwww.britishjr.org

[10] C. S. James, Analytical Chemistry of Foods 12005 edn, Chapman and Hall New York.

[11] O. S Lawal,. and Adebowale, K. O., Effect of acetylation and succinylation on solubility profile, water absorption capacity, oil absorption capacity and emulsifying properties of muncuna bean (Mucunapruriens) protein concentrate, Nahrung/Food, 2004.48 (2), 129-136.

[12] Marylyn"Groundnut, Egusi, Palm Oil, and Other Soups", in Foods of Sierra Leone and Other West African Countries: A Cookbook, Author House, 2012 p. 36.

[13] F. B., Ogunbanwo, National Agency for Food and Drug Administration and Control, Nigeria Proximate Composition And Fatty Acid Profile Of Nigerian Melon Seeds Life Science Archives (LSA) Volume - 1; Issue - 1; Year 2015. Page: 59 65 Available online at www.jpsscientificpublications.com

[14] J. O Ogundele,.., Oshodi, A. A. and. Amoo, I. A., Comparative Study of Amino Acid and Proximate Composition of Citurlluscolocynthis and Citrullus vulgaris Seeds. Pakistan Journal of Nutrition 201211 (3): 247-251.

[15] J. O Olaniyi, and Tella, B. A. Effects of nitrogen and potassium fertilizers on the growth, seed yield and nutritional values of egusi melon (Citrulluslanatus (thumb) manf) in Ogbomoso South west Nigeria International Research Journal of Plant Science 20112 (11): 328-331.

[16] E. S., Omoregie, Osagie, A. U.,. Glycemic indices and glyceic load of some Nigerian foods, Pakistan journal of nutrition, 2008 7: $710-716$.

[17] E. N., Onyeneke, Afam-Anene O. C. and Asinobi I. C. Manual of Food Recipe Development and Practicals. Egusi cake (Akpurakpu). 2017 Pp $23-26$.

[18] Onuh, O. M. and Igwemma, A. A.; Applied Statistical Techniques for Business and Basic Sciences. Second Edition. Skillmark Media Ltd., Owerri. (2007) Pp. 261 - 301.

[19] V. N., Osabor, Ogar, D. A., Okafor P. C. and Egbung, G. E. Department of Biochemistry, University of Calabar, Calabar, Nigeria. Pakistan Journal of Nutrition 2009. 8 (7): 1005-1008, ISSN 1680-5194 (C) Asian Network for Scientific Information, 2009

[20] U. Osagie, AAntinutritional factors in nutritional quality of plant foods Benin city, Post Harvest Research Unit. Department of biochemistry University of Benin, Nigeria.. 2010 
[21] G. Sunyer."Roles of glucose transport and glucose phosphorylation in muscle insulin resistance of NIDDM" (PDF). Diabetes. 2012 vol 45 (7): 915-25. doi: 10.2337/diab.45.7.915. PMID 8666143. Retrieved March 5, 2017.

[22] T. M. S., WoleverJenkins D. J. A., Jenkins A. L, Jesse R. G., The glycemic index: methodology and clinical implications American journal of clinical nutrition, 2003: 54: 846-854.

[23] T. M. S Wolever. Ketsman, A. L Jentans, Y. Vutesan, R. G
Tosse and D. J. A. Fentains,: Glycemic index of 102 complex carbohydrates foods in patients 200862.8715 - 935.

[24] T. M. S., Wolever, Relationship between dietary fiber content and composition in foods and the glycemic index. $\mathrm{Am} J$ ClinNutr [serial online].2009 51: 72-5. Available from (www.ajen.org).

[25] World Health Organization. Chronic diseases and their common risk factors. Archived 2016-10-17 at the Wayback Machine, Geneva. Accessed 30 August 2016. 